\title{
Correction to: Development of tables for classifying judo athletes according to maximal isometric strength and muscular power, and comparisons between athletes at different competitive levels
}

\author{
Braulio Henrique Magnani Branco 1,2,3,4 - Leonardo Vidal Andreato ${ }^{2,4}$. Eugenio Diniz Ribeiro ${ }^{5}$. \\ Humberto Garcia de Oliveira ${ }^{2,4} \cdot$ Felipe Natali Almeida ${ }^{2,3} \cdot$ Nelson Nardo Junior $^{6}$
}

Published online: 28 November 2020

(c) Springer-Verlag Italia S.r.l., part of Springer Nature 2020

Correction to: Sport Sciences for Health (2018) 14:607-614
https://doi.org/10.1007/s11332-018-0469-7

Unfortunately, some values of Table 1 have been published incorrectly in the original publication. The corrected values for classification for the absolute and relative plyometric tests for judo athletes are given below.

The original article can be found online at https://doi.org/10.1007/ s11332-018-0469-7.

Braulio Henrique Magnani Branco

brauliomagnani@live.com

1 Postgraduate Program in Health Promotion at the University Center of Maringá (UNICESUMAR), Maringá, Paraná, Brazil

2 Department of Physical Education of the University Center of Maringa (UNICESUMAR), Maringá, Paraná, Brazil

3 Department of Physiotherapy of the University Center of Maringa (UNICESUMAR), Maringá, Paraná, Brazil

4 Research Group in Physical Education, Physiotherapy, Sports, Nutrition and Performance (GEFFEND/UNICESUMAR), Maringá, Brazil

5 São Paulo State Judo Federation, São Paulo, Brazil

6 Physical Education Department of Maringá State University (UEM), Maringá, Paraná, Brazil 
Table 1 Classification for the absolute and relative plyometric tests for judo athletes

\begin{tabular}{|c|c|c|c|c|c|c|}
\hline \multirow[t]{2}{*}{ Classification } & \multicolumn{2}{|l|}{ PPU } & \multicolumn{2}{|l|}{ CMJ } & \multicolumn{2}{|l|}{ SJ } \\
\hline & Absolute (cm) & Relative ( $\mathrm{cm} \mathrm{kg}$ ) & Absolute (cm) & Relative $(\mathrm{cm} \mathrm{kg})$ & Absolute (cm) & Relative $(\mathrm{cm} \mathrm{kg})$ \\
\hline Very poor & $\leq 8.2$ & $\leq 635.4$ & $\leq 25.4$ & $\leq 1775.4$ & $\leq 23.4$ & $\leq 1690.7$ \\
\hline Poor & $8.3-10.9$ & $635.5-901.9$ & $25.5-29.4$ & $1775.5-2195.4$ & $23.5-26.4$ & $1690.8-1990.3$ \\
\hline Regular & $11.0-19.9$ & $902.0-1801.4$ & $29.5-39.8$ & $2195.5-3667.2$ & $26.5-37.4$ & 1990.4-3387.9 \\
\hline Good & $20.0-27.9$ & $1801.5-2369.7$ & $39.9-43.4$ & $3667.3-4208.3$ & $37.5-41.2$ & $3388.0-4029.4$ \\
\hline Excellent & $\geq 28.0$ & $\geq 2369.8$ & $\geq 43.5$ & $\geq 4208.4$ & $\geq 41.3$ & $\geq 4029.5$ \\
\hline
\end{tabular}

Relative values were obtained by multiplication of body mass vs centimeters

$P P U$ plyometric push-up, $C M J$ countermovement jump, $S J$ squat jump 